\title{
REVIEW of Marklen E. Konurbaev (2016) THE STYLE AND TIMBRE OF ENGLISH SPEECH AND LITERATURE. Palgrave Macmillan. ISBN 978-1-349-57827-6
}

\section{РЕЦЕНЗИЯ НА КНИГУ Marklen Е. Konurbaev (2016) THE STYLE AND TIMBRE OF ENGLISH SPEECH AND LITERATURE. Palgrave Macmillan. ISBN 978-1-349-57827-6}

The purpose of this book is to present an aspect of reading which is virtually overlooked in language and literature teaching: the way that a text sounds and, quite literally, communicates the writer's voice. Professor Konurbaev makes a through and passionate case that ignoring the oral dimension of a text obscures reading comprehension and literary appreciation. He is keen to acknowledge his debt to his supervisor and mentor the late Olga Akhmanova of Moscow State University, quoting her maxim of "Above all, listen to the implied sound message of the text in your mind's ear" in the Preface (p. ix). Olga Akhmanova would certainly not have been disappointed in this book as a continuation of her legacy, inter alia, to linguistics, stylistics, which all too often occupies an uncomfortable middle ground between linguistics proper and literature (Verdonk, 2002), and pedagogy.

Some readers may be unfamiliar with the term timbre and this is defined in the Introduction as the holistic image of the text forged by the interface of foregrounding, or prominence, and backgrounding, the ongoing and cumulative narrative. The premise, in line with functional linguistics, is that language is an open system of communicating meaning and that a choice of form has implications for meaning. Writers shape texts to manipulate the readers' response and they rely on the sensitivity of language to multiple often competing interpretations. This is a long way from the "slot and filler" linguistics, sentences parsed with almost no consideration of the words they contain, of which John Sinclair (1991) famously accused Generative Linguistics. Professor Konurbaev makes an interesting analogy with ancient Greek theatre where the actors acted as a foreground to the background of the chorus, the latter adding perspective to the unfolding action.

The first chapter enlarges on this basic understanding of timbre with the notion of timbre strings, "mental association[s] drawn in the course of reading between the words of the text" (p. 10). Meaning is created in a text through recognising and inferring the relationship between these observable elements and the writer's intention, which can never be fully grasped because the chain of associations always has a degree of the 
tenuous. The "structural" timbre strings are the most obvious as they can be described linguistically but there is a whole body of connections which very loosely fall under pragmatics, for example awareness of socio-cultural conventions and schema. The complex textuality captured by timbre strings is well illustrated (pp. 19-20) by a reference to a Stephen Fry work. The skillful analysis of the extract points out the subtleties and tensions in the text as Fry expresses his voice and challenges the reader to disambiguate competing versions of the reality of interpretation. This use of a corpus of authentic texts is a feature of the book throughout and surely one of its strongest recommendations.

This Chapter One very broadly fits into the first of two halves of The style and timbre of English speech and literature. The first half, Chapters One to Six, offer a detailed rationale for Professor Konurbaev's thesis and draw on a range of disciplines. The most interesting for me personally was Chapter Four, "A Glimpse of the Brain: The Mechanism of Mental Audition" and its insights into the world of neuroscience. As a practicing teacher, it confirmed my ardent belief, considered rather old-fashioned these days (cf. Harmer, 2009), that reading aloud is a valid classroom activity. The second half of the book, Chapters Seven to Ten, put the argument into context by examining four functional styles of English, from everyday speech to high literature. Much of the content in this part of the book could be used with students as classroom tasks, enhancing its value to teachers.

To demonstrate what I have pointed out as the book's key achievement, the exploitation of a corpus of authentic material, consider an extract from Dickens' A Tale of Two Cities, analysed on p. 182. Dickens describes the execution scene at the end of the book.

She kisses his lips; he kisses hers; they solemnly bless each other. The spare hand does not tremble as he releases it; nothing worse than a sweet, bright constancy is in the patient face. She goes next before him - is gone; the knitting-women count TwentyTwo. 'I am the Resurrection and the Life, saith the Lord: he that believeth in me, though he were dead, yet shall he live: and whosoever liveth and believeth in me shall never die'. The murmuring of many voices, the upturning of many faces, the pressing on of many footsteps in the outskirts of the crowd, so that it swells forward in a mass, like one great heave of water, all flashes away. Twenty-Three (Dickens, 1859/1974).

As Professor Konurbaev points out, the understatement of the narrative (note the simple Subject-Verb-Object clauses in the first sentence) belies the emotiveness of the scene. The biblical reference is where "the timbre gushes out" and reconnects the reader to the terrible pathos. Professor Konurbaev makes the crucial point that the " $[\mathrm{t}] \mathrm{he}$ text does not belong to anyone" - how can it when all the words are unsaid? The meaning is loaned to each and every reader and each reading may well reveal new timbres to be discovered, wherein probably lies one of the main joys of reading.

The style and timbre of English speech and literature is an important book for anyone with a serious interest in text, and I would extend that interest to languages other than English. For me, the outstanding feature of the book is the wealth of examples used to support the arguments made, sources ranging from to Alistair Cooke's Letters from America to The Koran, via Shakespeare and Ishiguro. Above all, it provides a convincing 
argument that language has endless potential as a vehicle of communication but that this needs to be unlocked through analysis which is sensitive to the many manifestations, explicit and latent, of vocalised meaning. Reading The style and timbre of English speech and literature is a first step to true recognition of this.

(C) Wayne Rimmer, 2017

\section{REFERENCES}

Dickens, C. (1859/1974) A Tale of Two Cities. Moscow: Progress Publishers.

Harmer, J. (2009) Is reading aloud allowed?, English Teaching Professional 65/4.

Sinclair, J. (1991) Corpus, concordance and collocation. Oxford: Oxford University Press.

Verdonk, P. (2002) Stylistics. Oxford: Oxford University Press.

For citation:

Rimmer, W. (2017) Review of Marklen E. Konurbaev (2016) The Style and Timbre of English Speech and Literature. Palgrave MacMillan. Russian Journal of Linguistics, 21 (2), 438-440.

\section{Bio Note:}

Wayne Rimmer, Co-ordinator of IATEFL PronSIG (Kent, UK). Contact Information: e-mail: PronSIG@iatefl.org

Для цитирования:

Rimmer W. Review of Marklen E. Konurbaev (2016) The Style and Timbre of English Speech and Literature. Palgrave MacMillan // Вестник Российского университета дружбы народов. Серия: Лингвистика. 2017. Т. 21. № 2. С. 438-440.

\section{Сведения об авторе:}

Уэйн Реймер, координатор IATEFL PronSIG (Кент, Великобритания). Контактная информация: e-mail: PronSIG@iatefl.org 